\title{
GROWTH AND MACRONUTRIENT ABSORPTION IN 'SABARÁ' JABUTICABA GENOTYPES CULTIVATED IN NUTRIENT SOLUTION
}

\author{
CRESCIMENTO E MARCHA DE ABSORÇÃO DE MACRONUTRIENTES EM \\ GENÓTIPOS DE JABUTICABEIRA 'SABARA' CULTIVADOS EM SOLUÇÃO \\ NUTRITIVA
}

\section{Martha Cristina Pereira RAMOS ${ }^{1}$; José Carlos Moraes RUFINI ${ }^{2}$; Adriano Gonçalves de CAMPOS ${ }^{1}$; Matheus Pena CAMPOS ${ }^{1}$; Mayara Neves Santos GUEDES ${ }^{3}$; Janaina Canaan Rezende de SOUZA ${ }^{1}$}

1. Mestre em Ciências Agrárias, Universidade Federal de São João del Rei, Departamento de Agronomia, Sete Lagoas, MG, Brasil. marthinha.ramos@yahoo.com.br. 2. Professor associado, Universidade Federal de São João del Rei, Departamento de Agronomia, Sete Lagoas, MG, Brasil. 3. Bolsista PNPD/CAPES, Universidade Federal de São João del Rei, Departamento de Agronomia, Sete Lagoas, MG, Brasil.

\begin{abstract}
The knowledge about growth and nutrient accumulation can help improve fertilizer efficiency in the production of jabuticaba seedlings, which is still carried out in an empirical way. This study aimed at determining the growth and macronutrient uptake in 'Sabara' jabuticaba genotypes grown in nutrient solution. The experiment was carried out in a completely randomized design in split plots, with four replications. In the main plots three jabuticaba genotypes (J001, J005 and J012) were cultivated in nutrient solution and six evaluation periods (at 60,120, 180, 240, 300 and 360 days) in the sub-plots were evaluated. Plant height, root length, stem diameter, leaf area index and dry matter (root, stem and leaves) in each period were evaluated. The accumulation of macronutrients in different plant organs was determined, as well as the accumulation of nutrients as a function of time adjusted to the linear model. The results showed that the cultivation in nutrient solution was efficient in the production of Sabara jabuticabeira seedlings. There was no difference in macronutrient growth and absorption among jabuticaba genotypes grown in nutrient solution. 'Sabará jabuticaba plants accumulated (in mg plant ${ }^{-1}$ ) 559 of N, 45 of P, 443 of K, 363 of Ca, 59 of Mg and 82 of S. The distribution of macronutrient accumulations in jabuticaba showed the following order: leaves $>$ stem $>$ roots.
\end{abstract} requirement.

KEYWORDS: Myrciaria jabuticaba. Mineral nutrition. Nutrient accumulation. Nutritional

\section{INTRODUCTION}

Jabuticaba (Myrciaria jabuticaba (Vell) Berg) is a fruit species native to Brazil, belonging to the Myrtaceae family. The lack of knowledge about production results in the low use of jabuticaba, which contributes to its genetic erosion (WAGNER JÚNIOR et al., 2017). However, it is a fruit that has high potential for food use.

The fruits have functional properties, due to their high contents of phenolic compounds and flavonoids (GUEDES et al., 2014), which has aroused interest in the expansion of new orchards. However, the expansion of jabuticaba cultivation requires the availability of genetic material that has characteristics of economic interest for its propagation.

Mineral nutrition is an ally for the production of quality seedlings, besides being a fundamental factor to reach homogeneity, with rapid development and precocity (ALEXANDRE BESSA et al., 2013). Currently, the management of mineral nutrition in the formation of jabuticaba seedlings is carried out empirically by nurserymen, due to the lack of knowledge regarding the nutritional aspects of this culture. An alternative would be the cultivation in nutrient solutions, once it is an unpublished practice, little used in the production of fruit tree seedlings.

Nutrient uptake dynamics in the plant and the accumulation of nutrients in the different organs allow to evaluate the growth of the whole plant and the contribution of the different organs to the total growth (BENINCASA, 2003). In addition, for adequate nutrition, it is necessary to know the amount, ratio and the accumulation of nutrients in the dry matter over time. Nutritional imbalance can cause damage to the plants, resulting in delayed development and possible morphological and physiological changes (FRANCO et al., 2007).

The nutrient uptake rate is an important reference for nutrient supply in adequate amounts to 
the plants, during several stages of their development (GURGEL et al., 2010). In this context, several studies on mineral nutrition were conducted with fruits such as star fruit (FREITAS et al., 2011; ROZANE et al., 2011a), guava (FRANCO et al., 2007; FRANCO et al., 2008), citrus (SOUZA et al., 2013), pear (SOUZA et al., 2015) and peach (SOUZA et al., 2011).

The adequate mineral nutrition of jabuticaba seedlings can contribute to the maximum expression of the genetic potential, as well as to the obtention of healthy and vigorous plants, capable of suggesting the selection and adaptation of genotypes to different soil conditions. Therefore, the objective of this study was to determine the growth and progression of macronutrient uptake in the initial growth of 'Sabará' jabuticaba genotypes cultivated in nutrient solution.

\section{MATERIAL AND METHODS}

The experiment was conducted in a greenhouse located at latitude $19^{\circ} 28^{\prime} \mathrm{S}$, longitude $44^{\circ} 11^{\prime} \mathrm{W}$ and $800 \mathrm{~m}$ altitude, at Universidade Federal de São João del-Rei - CSL.

The experiment was carried out a completely randomized design in sub-plots in the time, with four replications. In the main plots three jabuticaba genotypes (J001, J005 and J012) were cultivated in nutrient solution and six evaluation periods (at 60, 120, 180, 240, 300 and 360 days after transplanting - DAT) in the sub-plots were evaluated, and each experimental unit was composed of four plants.

Seeds collected ex situ from 'Sabará' mother plants in Prudente de Moraes (MG). The selected seedlings with $15 \mathrm{~cm}$ height at six months of age were used. The seedlings were transplanted to 11-L virgin polypropylene pots, using perlite as a substrate, with four seedlings per pot, equidistant, each positioned in one quadrant. The seedlings were kept for 15 days in complete nutrient solution, diluted to $25 \%$ of the usual concentration (CASTELLANE; ARAÚJO, 1995) for adaptation. After 15 days of transplanting, the plants were submitted to the complete nutrient solution until reaching 360 days after transplanting.

The nutrient solution, kept in a 450-L tank, had the following concentrations of nutrients, in $\mathrm{mg}$ $\mathrm{L}^{-1}: \mathrm{N}=222.5 ; \mathrm{P}=61.9 ; \mathrm{K}=426.2 ; \mathrm{Ca}=139.9 ; \mathrm{Mg}$ $=24.3 ; \mathrm{S}=32.4$ and, in $\mu \mathrm{g} \mathrm{L}^{-1}$ for $\mathrm{B}=498 ; \mathrm{Cu}=48$; $\mathrm{Fe}=5000 ; \mathrm{Mn}=419 ; \mathrm{Mo}=52 ; \mathrm{Zn}=261$, according to CASTELLANE AND ARAÚJO (1995).
The nutrient solution was pumped through a motor-pump assembly, traversing the vessel sequence, and distributed via drippers at an average flow rate of $0.43 \mathrm{~L} \mathrm{~min}^{-1}$, with irrigations of $10 \mathrm{~min}$ every hour throughout the day. The nutrient solution was renewed every two weeks.

The $\mathrm{pH}$ of the solution was monitored daily with a portable $\mathrm{pH}$ meter and adjusted to $5.5 \pm 0.5$ with $0.1 \mathrm{~mol} \mathrm{~L}^{-1} \mathrm{NaOH}$ or $\mathrm{HCl}$ solution, and kept constant throughout the experiment; the electrical conductivity of the solution was monitored and maintained with a value lower than $2.4 \mathrm{dS} \mathrm{m}^{-1}$, as indicated for myrtaceae, according to (TÁVORA et al., 2001).

Every 60 days were evaluated: plant height $(\mathrm{cm})$, from the plant collar to the end of the last expanded leaf; root length $(\mathrm{cm})$, both analyzed with the aid of a graduated ruler; stem diameter $(\mathrm{cm})$, evaluated at $5 \mathrm{~cm}$ from the plant collar with the aid of a digital caliper; leaf area $\left(\mathrm{cm}^{2}\right)$, by the length $\mathrm{x}$ width method, according to LIMA et al. (2012). The fresh plants were sectioned into roots, stems and leaves and placed in paper bags and dried in a forced-air oven for dry matter quantification and subsequent determination of macronutrient concentrations in the plant tissue. Dickson quality index (DQI) was also determined (DICKSON et al., 1960), using the equation DQI = $\mathrm{DMT} /(\mathrm{RAD}+\mathrm{RPAR})$, where DMT is the total dry matter (roots, stems and leaves), RPAR is the ratio shoot dry matter/root dry matter (SDM/RDM) and RAD is the ratio plant height/stem diameter.

For the determination of mineral contents, nitroperchloric digestion was used; the contents of $\mathrm{P}$ and $\mathrm{S}$ were evaluated by colorimetry; $\mathrm{K}$, by flame emission photometry; $\mathrm{Ca}$ and $\mathrm{Mg}$, by atomic absorption spectrophotometry; total $\mathrm{N}$, by the Kjeldahl method (SILVA, 1999;MALAVOLTA et al., 1997). Using the concentration of nutrients and of the dry matter, the accumulation of nutrients in the different plant organs was calculated, obtained by the product between nutrient content and the dry matter corresponding to each part of the plant and evaluated period.

Analyses of variance ( $\mathrm{F}$ test) were performed for the evaluated parameters. The means obtained as a function of the jabuticaba genotypes were compared by the Tukey-test at 0.05 probability level, whereas means relative to evaluation periods of the plants were evaluated by regression analysis. For the statistical analysis, the $\mathrm{R}$ software (data package ExpDes) FERREIRA et al. (2013) was used. 


\section{RESULTS AND DISCUSSION}

For the variables root length, stem diameter, leaf dry matter and leaf area, no significant differences were found between jabuticaba genotypes (Table 1 and 2).

Table 1. Plant height $(\mathrm{cm})(\mathrm{PH})$, root length $(\mathrm{cm})(\mathrm{RL})$, stem diameter $(\mathrm{cm})(\mathrm{SD})$, Dickson quality index (DQI), and leaf area $\left(\mathrm{cm}^{2}\right)(\mathrm{LA})$ obtained for the three 'Sabará' jabuticaba genotypes.

\begin{tabular}{llllll}
\hline Genotype & PH & RL & SD & DQI & LA \\
\hline J001 & $41.68 \mathrm{a}$ & $36.27 \mathrm{a}$ & $49.9 \mathrm{a}$ & $2.77 \mathrm{a}$ & $214.60 \mathrm{a}$ \\
J005 & $37.84 \mathrm{~b}$ & $35.36 \mathrm{a}$ & $50.0 \mathrm{a}$ & $2.57 \mathrm{a}$ & $177.52 \mathrm{a}$ \\
J012 & $37.81 \mathrm{~b}$ & $33.99 \mathrm{a}$ & $46.8 \mathrm{a}$ & $2.10 \mathrm{~b}$ & $181.97 \mathrm{a}$ \\
\hline CV & 13.91 & 13.31 & 10.24 & 22.94 & 45.70 \\
MEAN & 39.11 & 35.21 & 48.9 & 2.48 & 191.36 \\
\hline
\end{tabular}

Values followed by the same letter in the column do not differ by the Tukey test at $5 \%$.

Considering the growth variables evaluated together to obtain the DQI (Table 1), it can be implied that the three genotypes presented several similar characteristics in nutrient solution, a fact that can be considered beneficial from the agronomic point of view, mainly in the fertilization management of this fruit, in addition to good quality seedlings.
The jabuticaba genotypes showed a different behavior: genotype J001 showed higher growth, shoot and root dry matter, while genotype J003 had lower root and stem dry matter. In general, genotype J001 obtained better shoot development, in relation to the other genotypes evaluated (Table 2).

Table 2. Root dry matter (g) (RDM), shoot dry matter (g) (SHDM), stem dry matter (SDM), leaf dry matter (LDM), plant dry matter (g) (PDM),

\begin{tabular}{llllll}
\hline Genotype & RDM & SHDM & SDM & LDM & PDM \\
\hline J001 & $2.70 \mathrm{a}$ & $14.23 \mathrm{a}$ & $5.53 \mathrm{a}$ & $8.70 \mathrm{a}$ & $16.93 \mathrm{a}$ \\
J005 & $2.03 \mathrm{~b}$ & $12.82 \mathrm{ab}$ & $5.17 \mathrm{a}$ & $7.64 \mathrm{a}$ & $15.29 \mathrm{ab}$ \\
J012 & $2.03 \mathrm{~b}$ & $11.18 \mathrm{~b}$ & $4.09 \mathrm{~b}$ & $7.09 \mathrm{a}$ & $13.22 \mathrm{~b}$ \\
\hline CV & 23.19 & 30.58 & 29.01 & 32.45 & 29.31 \\
MEAN & 2.40 & 12.74 & 4.93 & 7.81 & 15.15 \\
\hline
\end{tabular}

Values followed by the same letter in the column do not differ by the Tukey test at $5 \%$.

The jabuticaba seedlings showed adequate growth, with a significant effect of cultivation time on all analyzed variables. A linear behavior was observed by the regression study for the growth variables: length (shoot and root), stem diameter, root, shoot and total dry matter, DQI and leaf area (Figure 1).

Average root length was greater than average plant height, being observed up to 180 DAT, evidencing a greater relative investment in root than in shoot production (Figure 1A). A lower shoot/root ratio tends to be favorable in soils with low fertility levels, since there will be a larger root surface to supply plant needs. It can also be inferred that, up to $180 \mathrm{DAT}$, there was a greater translocation of photoassimilates to the root system, which limited shoot development, reducing the photosynthetically active area.
At the moment when the root system is more developed, it leads the seedlings to have a higher shoot development capacity (which stabilized up to 300 DAT), justifying its greater length at the end of the experimental period.

The linear behavior observed for the growth variables quantified in this study can be explained by the initial development stages, which corroborate the data observed in star fruit grown in nutrient solution (FREITAS et al., 2011; ROZANE et al., 2011a).

According to SCALON et al. (2001), the larger stem diameter suggests greater partitioning of shoot photoassimilates, while the increase in leaf area index raises the radiation absorption surface and, consequently, increases plant biomass, which defines its development (TAIZ; ZEIGER, 2006). 

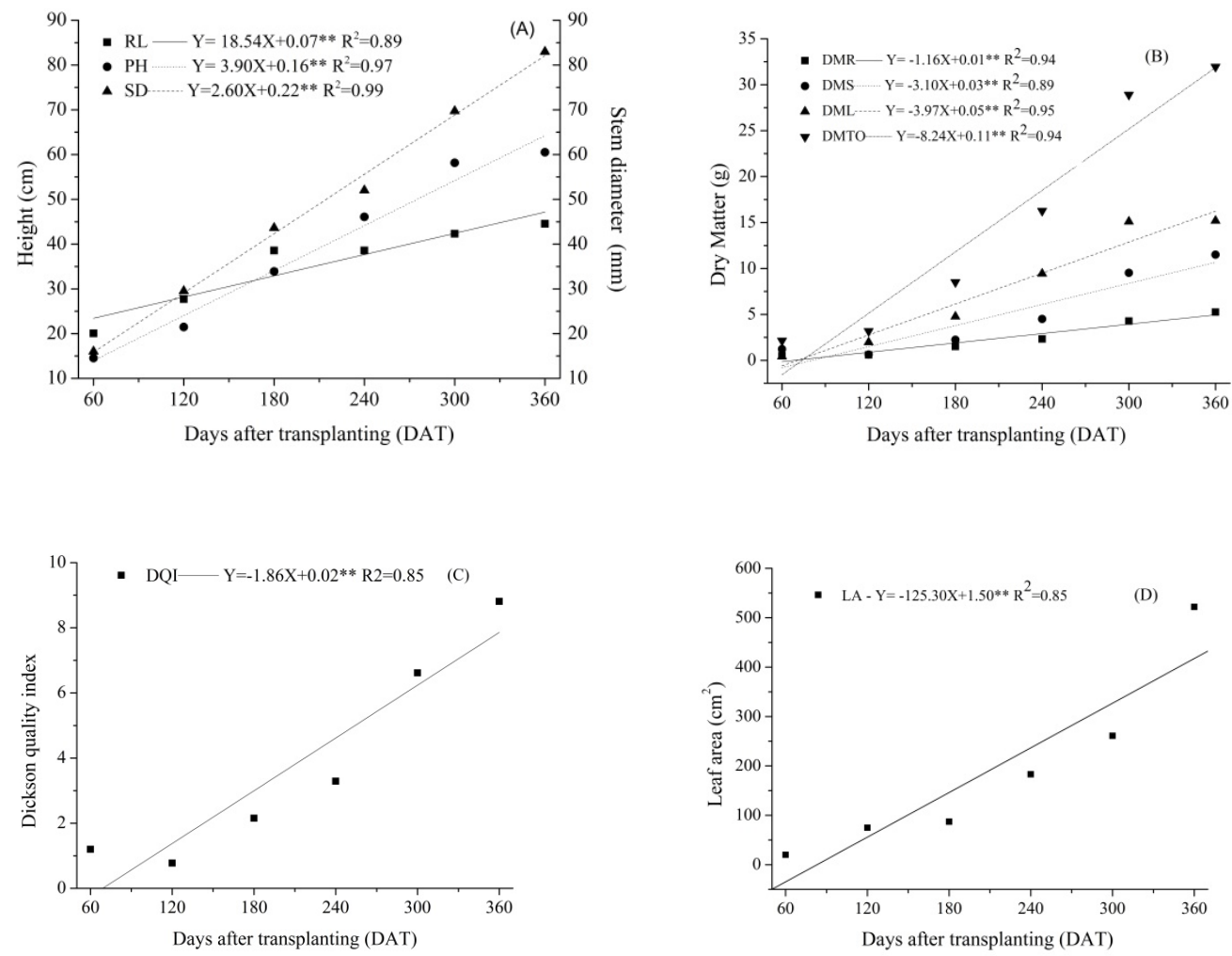

Figure 1. Growth variables of 'Sabara' jabuticaba as a function of days after transplanting (DAT): (A) root length $(\mathrm{RL})(\mathrm{cm})$, plant height $(\mathrm{PH})(\mathrm{cm})$, stem diameter $(\mathrm{SD})(\mathrm{cm}),(\mathrm{B})$ dry matter (root-DMR, stemDMS, leaf-DML and total - DMTO) (g), (C) Dickson quality index (DQI) and (D) leaf area-(LA) $\left(\mathrm{cm}^{2}\right)$.

Table 3 shows that at the end of the experimental period, at 360 DAT for the nutrient solution, a maximum accumulation of $31.94 \mathrm{~g}$ dry matter was observed for the plants, with $5.24 \mathrm{~g}$ of the root, $11.50 \mathrm{~g}$ of the stem and $15.19 \mathrm{~g}$ of the leaves in the following order: leaves $(47.55 \%)>$ stem $(36.00 \%)>$ roots $(16.40 \%)$. According to LAVENDER (1984), plants grown with greater availability of water and nutrients have higher shoot than root rates. Leaf dry matter represented almost half of the total dry matter accumulated by the plant during its initial growth, which may be related to its function as a source of photoassimilates and better utilization of the nutrients absorbed by the root system available in the nutrient solution.

Table 3. Root dry matter (g) (RDM), stem dry matter (SDM), leaf dry matter (LDM), dry matter total $(\mathrm{g})(\mathrm{DMTO})$ as a function of days after transplanting (DAT).

\begin{tabular}{lllll} 
DAT & RDM & SDM & LDM & DMTO \\
\hline 60 & 0.489 & 1.22 & 0.428 & 2.137 \\
120 & 0.583 & 0.626 & 1.962 & 3.171 \\
180 & 1.502 & 2.236 & 4.764 & 8.502 \\
240 & 2.327 & 4.500 & 9.439 & 16.266 \\
300 & 4.271 & 9.526 & 15.105 & 28.902 \\
360 & 5.247 & 11.501 & 15.197 & 31.945 \\
\hline CV & 1.968 & 4.561 & 6.456 & 12.880 \\
MEAN & 2.403 & 4.935 & 7.816 & 15.154 \\
\hline
\end{tabular}

CV: coefficient of variation.

In a conventional cultivation for jabuticaba seedling production using soil as a substrate, Danner et al. (2007) obtained averages for plant height, stem diameter, root and shoot dry matter, lower than 
those reported in this study, showing the viability of cultivation in nutrient solution and a reduction in the time of production and formation of jabuticaba seedlings.

The linear behavior for the growth variables of jabuticaba plants obtained in this study can be explained by the result of the availability of nutrients present in the nutrient solution during growth. The nutrient solution is homogeneous, in which the nutrients are available as ions in adequate amounts (PUGA et al., 2010).
In relation to the accumulation of macronutrients in initial growth of jabuticaba, except for the accumulated amounts of nutrients $\mathrm{P}$ and $\mathrm{K}$ in the roots, there was no interaction between genotypes and cultivation time for the other nutrients in the different plant organs. From 300 days of cultivation, genotype J001 obtained approximately $30 \%$ greater effectiveness in the accumulation of $\mathrm{P}$ and $\mathrm{K}$ in the roots in relation to genotypes J005 and J012 (Table 4).

Table 4. Genotype splitting averages (J001, J005 and J012) at 60, 120, 180, 240, 300 and 360 days after transplanting (DAT), for the accumulation of $\mathrm{P}$ and $\mathrm{K}$ in 'Sabará' jabuticaba roots grown in nutrient solution.

\begin{tabular}{llll}
\hline DAT & Genotypes & $\begin{array}{c}\text { P } \\
\text { mg plant }^{-1}\end{array}$ & K \\
\hline $\mathbf{6 0}$ & J001 & 0.21 & 1.17 \\
& J005 & 0.24 & 1.21 \\
& J012 & 0.19 & 0.96 \\
\hline $\mathbf{1 2 0}$ & J001 & 0.85 & 5.15 \\
& J005 & 0.91 & 5.29 \\
& J012 & 0.90 & 4.78 \\
\hline $\mathbf{1 8 0}$ & J001 & 1.51 & 10.02 \\
& J005 & 1.50 & 10.24 \\
& J012 & 1.24 & 8.60 \\
\hline $\mathbf{2 4 0}$ & J001 & 2.71 & 19.62 \\
& J005 & 2.29 & 16.79 \\
& J012 & 2.48 & 17.60 \\
\hline $\mathbf{3 0 0}$ & J001 & $6.79 \mathrm{a}$ & $45.19 \mathrm{a}$ \\
& J005 & $4.30 \mathrm{~b}$ & $30.28 \mathrm{~b}$ \\
& J012 & $4.49 \mathrm{~b}$ & $29.66 \mathrm{~b}$ \\
\hline $\mathbf{3 6 0}$ & J001 & $10.01 \mathrm{a}$ & $54.83 \mathrm{a}$ \\
& J005 & $6.88 \mathrm{~b}$ & $45.91 \mathrm{~b}$ \\
& J012 & $6.66 \mathrm{~b}$ & $39.14 \mathrm{~b}$ \\
\hline
\end{tabular}

The greater accumulation of $\mathrm{P}$ and $\mathrm{K}$ by genotype J001, at 360 days after transplantation, does not necessarily result in higher efficiency, since genotypes J005 and J012 obtained the same growth performance (Table 4); however, the greater accumulation of nutrients in the plant tissues can constitute reserves necessary in the establishment in the field and under conditions of biotic and abiotic stress. According to Taiz and Zeiger (2013), the needs of mineral elements change, even as the plant grows and develops.

The average accumulation of macronutrients in jabuticaba at 360 days after transplanting was, in mg plant ${ }^{-1}$ : in the root $(\mathrm{N}=48.38 ; \mathrm{P}=7.9 ; \mathrm{K}=46.6$; $\mathrm{Ca}=36.9 ; \mathrm{Mg}=8.9 ; \mathrm{S}=13.2)$, in the stem $(\mathrm{N}=135.6$; $\mathrm{P}=17.8 ; \mathrm{K}=149.3 ; \mathrm{Ca}=127.0 ; \mathrm{Mg}=26.8 ; \mathrm{S}=26.2)$ and in the leaves $(\mathrm{N}=370.5 ; \mathrm{P}=19.0 ; \quad \mathrm{K}=247.09$; $\mathrm{Ca}=199.3 ; \mathrm{Mg}=23.2 ; \mathrm{S}=42.6)$. As the force for the absorption of inorganic solutes is commonly transpiration, nutrients from the nutrient solution tend to accumulate in organs that with higher transpiration rates, such as leaves.

In the literature, there are no reports on nutrient concentrations in plant tissue for the jabuticaba crop. With the knowledge of the nutrient contents of leaves, it is possible to perform foliar diagnosis and to compare them with nutritional standards, since the leaf is the organ that best represents the nutritional state of the plant, as it is where the main metabolic processes occur FAQUIN (2002).

'Sabará' jabuticaba plants accumulated: $559,45,443,363,59$ and $82 \mathrm{mg} \mathrm{plant}^{-1}$ of N, P, K, $\mathrm{Ca}, \mathrm{Mg}$ and $\mathrm{S}$, respectively. The average nutrient accumulation presented a linear adjustment for the evaluated macronutrients, possibly due to the fact that the plants are in the initial growth phase (Table 5). Results similar of the present study were 
obtained by Souza et al. (2018), showed a linear increase in the accumulation of macronutrients in
'Paulista' and 'Sabará' jabuticaba in nutrient solution.

Table 5. Macronutrient accumulation as nitrogen $(\mathrm{N})$, phosphorus $(\mathrm{P})$, potassium $(\mathrm{K})$, calcium $(\mathrm{Ca})$, magnesium $(\mathrm{Mg})$ and sulfur $(\mathrm{S})$ in roots, stems and leaves of 'Sabará' jabuticaba grown in nutrient solution, as a function of days after transplanting.

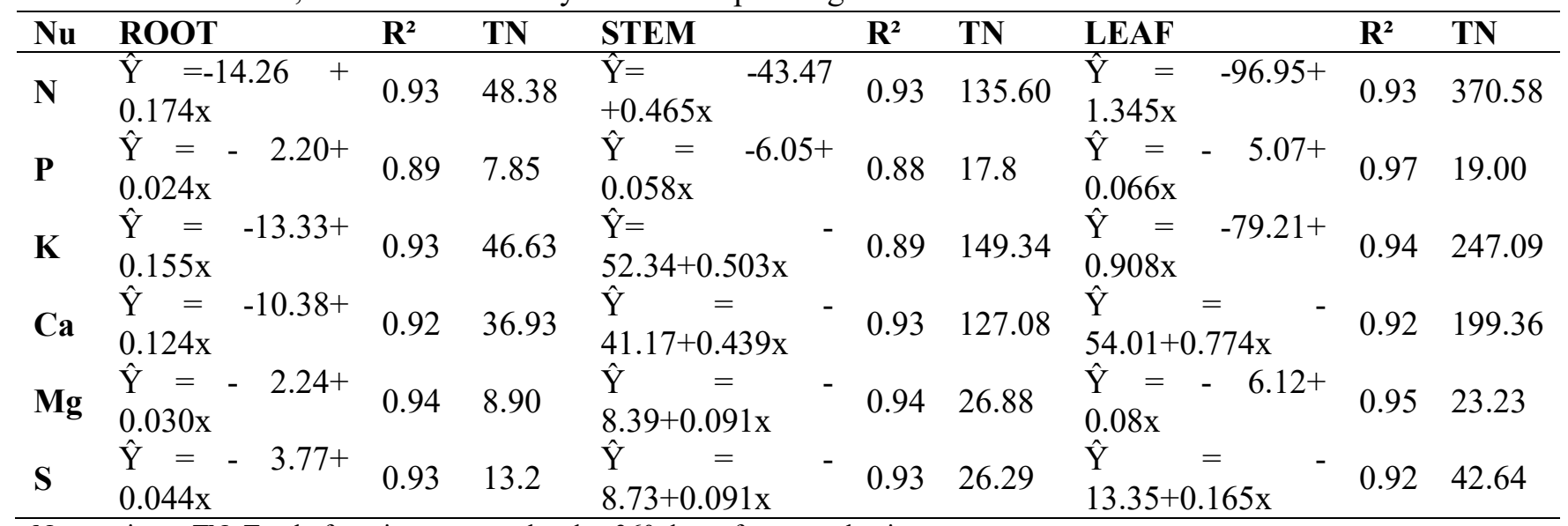

Nu: nutrients, TN: Total of nutrients accumulated at 360 days after transplanting.

In studies conducted with 'Paluma' and 'Século XXI' guava fruits in nutrient solution, linear and quadratic increments for leaf, stem and root nutrients were observed (FRANCO et al., 2007). In another study, Augostinho et al. (2008) observed that 'Pedro Sato' guava seedlings had a linear adjustment only in the accumulation of $\mathrm{Mg}$ in leaves and stem, and of $\mathrm{Mn}$ in the stem and, in the other nutrients, sigmoidal adjustments were made for the accumulation in leaves, stems and roots.

The distribution of macronutrient accumulation in jabuticaba had the following order: leaves $>$ stem $>$ roots, coinciding with the pattern obtained for the accumulated dry matter over time, while at 360 DAT, the accumulation of macronutrients in the plant showed the following sequence: $\mathrm{N}>\mathrm{K}>\mathrm{Ca}>\mathrm{S}>\mathrm{Mg}>\mathrm{P}$.

Nitrogen was found at higher contents in the leaves, stem, followed by the root. $\mathrm{N}$ is a component of amino acids and proteins, acts on cell division and chlorophyll production (EPSTEIN; BLOOM, 2006); (MARSCHNER; MARSCHNER, 2012), high demand in the initial phase of vegetative growth in this fruit life cycle.

Potassium was the second most required nutrient in the initial phase of jabuticaba seedlings development, with the leaves responsible for more than $50 \%$ accumulation of this mineral. This high nutrient requirement for plants is possibly due to the intense metabolic activity during vegetative growth.

In this study, the jabuticaba plants grew and developed in nutrient solution without presenting symptoms of deficiency or nutritional excess, proving to be an efficient method for seedling production.

\section{CONCLUSIONS}

The cultivation in nutrient solution proved efficient in the production of jabuticaba seedlings.

The tested genotypes did not show differences in relation to plant initial growth.

The genotypes accumulated different amounts of $\mathrm{P}$ and $\mathrm{K}$ in their roots.

The distribution of macronutrient accumulations in jabuticaba showed the following order: leaves $>$ stem $>$ roots.

The accumulation of macronutrients in jabuticaba plants showed the following order: $\mathrm{N}>\mathrm{K}$ $>\mathrm{Ca}>\mathrm{S}>\mathrm{Mg}>\mathrm{P}$.

\section{ACKNOWLEDGEMENTS}

The authors would like to thank CAPES, for the grant provided; and FAPEMIG, for research funding.

RESUMO: O conhecimento sobre o crescimento e o acúmulo de nutrientes poderá contribuir para a melhoria da eficiência da adubação na produção de mudas de jabuticabeira, que ainda é realizada de forma empírica. Neste estudo, objetivou-se determinar o crescimento e a marcha de absorção de macronutrientes em genótipos de jabuticabeira Sabará cultivados em solução nutritiva. O experimento conduzido em delineamento 
inteiramente casualizado em parcelas subdivididas, com quatro repetições. Nas parcelas principais, foram utilizados três genótipos de jabuticabeira (J001, J002 e J003) e, nas subparcelas, foram avaliados seis períodos de avaliação (aos 60, 120, 180, 240, 300 e 360 dias). Avaliou-se altura das plantas, comprimento das raízes, diâmetro do caule, índice de área foliar e matéria seca (raiz, caule, folhas) em cada período. Foi determinado o acúmulo de macronutrientes nos diferentes órgãos das plantas, bem como, o acúmulo de nutrientes em função do tempo ajustado ao modelo linear. Os resultados demonstraram que o cultivo em solução nutritiva foi eficiente na produção de mudas de jabuticabeira Sabará. Não houve diferença no crescimento e absorção de macronutrientes entre os genótipos de jabuticaba cultivados em solução nutritiva. As plantas de jabuticaba 'Sabará' acumularam (em mg planta ${ }^{-1}$ ) 559 de N, 45 de P, 443 de K, 363 de Ca, 59 de Mg e 82 de S. A distribuição das acumulações de macronutrientes na jabuticaba mostrou a seguinte ordem: folhas $>$ caule $>$ raízes.

PALAVRAS CHAVE: Myrciaria jabuticaba. Nutrição mineral. Acúmulo de nutrientes. Exigência nutricional.

\section{REFERENCES}

ALEXANDRE BESSA, L.; SILVA, F. G.; MOREIRA, M. A.; TEODORO, J. P. R.; SOARES, F. A. L. Growth and nutrient accumulation of Anacardium othonianum Rizz. seedlings grown in nutrient solution. Chilean journal of agricultural research, v. 73, n.3, p. 301-308, 2013. http://dx.doi.org/10.4067/S071858392013000300014

AUGOSTINHO, L. M. D.; PRADO, R. M.; ROZANE, D. E.; FREITAS, N. Acúmulo de massa seca e marcha de absorção de nutrientes em mudas de goiabeira 'Pedro Sato'. Bragantia, v. 67, n.3, p. 577-585, 2008. http://dx.doi.org/10.1590/S0006-87052008000300004

DANNER, M. A.; CITADIN, I.; JUNIOR, A. A. F.; ASSMANN, A. P.; MAZARO, S. M.; SASSO, S. A. Z. Formação de mudas de jabuticabeira (Plinia sp.) em diferentes substratos e tamanhos de recipientes. Revista Brasileira de Fruticultura, v. 29, n.1, p. 179-182, 2007. http://dx.doi.org/10.1590/S010029452007000100038

EPSTEIN, E.; BLOOM, A. J. Nutrição mineral das plantas: princípios e perspectivas. Editora Planta, 2006.

FRANCO, C. F.; PRADO, R. M.; BRAGHIROLLI, L. F.; ROZANE, D. E . Curva de crescimento e marcha de absorção de macronutrientes em mudas de goiabeira. Revista Brasileira de Ciência do Solo, v. 31, n.6, p. 1429-1437, 2007. http://dx.doi.org/10.1590/S0100-06832007000600020

FRANCO, C. F.; PRADO, R. M.; BRAGHIROLLI, L. F; ROZANE, D. E. Marcha de absorção dos micronutrientes para mudas de goiabeiras cultivares Paluma e Século XXI. Bragantia, v. 67, n.1, p. 83-90, 2008. http://dx.doi.org/10.1590/S0006-87052008000100010.

FREITAS, N.; PRADO, R.M.; ROZANE, D.E.; TORRES, M.H.; AROUCA, M.B . Marcha de absorção de nutrientes e crescimento de mudas de caramboleira enxertada com a cultivar nota-10. Semina: Ciências Agrárias, v. 32, n.4, p. 1231-1242, 2011. http://dx.doi.org/10.5433/1679-0359.2011v32n4p1231

GUEDES, M. N. S.; RUFINI, J. C. M.; AZEVEDO, A. M.; PINTO, N. A. V. D. Fruit quality of jabuticaba progenies cultivated in a tropical climate of altitude. Fruits, v. 69, p. 449-458, 2014. https://doi.org/10.1051/fruits/2014030

GURGEL, M. T.; UYEDA, C. A.; GHEYI, H. R.; OLIVEIRA, F. H. T.; FERNANDES, P. D.; SILVA, F. V. Crescimento de meloeiro sob estresse salino e doses de potássio. Revista Brasileira de Engenharia Agrícola e Ambiental, v. 14, n.1, p. 3-10, 2010. http://dx.doi.org/10.1590/S1415-43662010000100001 
MALAVOLTA, E.; VITTI, G. C.; DE OLIVEIRA, S. A. Avaliação do estado nutricional das plantas: principios e aplicações. Associação Brasileira para Pesquisa da Potassa e do Fosfato, 1997.

MARSCHNER, H.; MARSCHNER, P. Marschner's Mineral Nutrition of Higher Plants. Academic Press, 2012.

ROZANE, D. E.; PRADO, R. M.; NATALE, W.; ROMUALDO, L. M.; SOUZA, H. A.; SILVA, S. H. M. G. Produção de mudas de caramboleiras 'B-10' e 'Golden Star': I - parâmetros biológicos. Revista Brasileira de Fruticultura, v. 33, n.4, p. 1300-1307, 2011a. http://dx.doi.org/10.1590/S0100-29452011000400031

SILVA, F. C.; EMBRAPA-SOLOS; AGROPECUÁRIA, E. I. Manual de análises químicas de solos, plantas e fertilizantes. Embrapa Comunicação para Transferência de Tecnologia, 1999.

SOUZA, A. D. G; CHALFUN, N. N. J.; FAQUIN, V.; SOUZA, A. A. Production of peach grafts under hydroponic conditions. Ciência e Agrotecnologia, v. 35, n.2, p. 322-326, 2011.

http://dx.doi.org/10.1590/S1413-70542011000200013

SOUZA, A. D. G.; FAQUIN, V.; CHALFUN, N. N.; SOUZA, A. A. Produção de mudas de tangerineira 'Ponkan' em sistema hidropônico. Revista Ciência Agronômica, v.44, n.4, p. 902-909, 2013. http://dx.doi.org/10.1590/S1806-66902013000400029

SOUZA, A. D. G.; CHALFUN, N. N. J.; FAQUIN, V.; SOUZA, A. A.; NETO, A. L. S. Massa seca e acúmulo de nutrientes em mudas enxertadas de pereira em sistema hidropônico. Revista Brasileira de Fruticultura, v. 37, n.1, p. 240-246, 2015. http://dx.doi.org/10.1590/0100-2945-020/14

SOUZA, J. C. R. D.; RUFINI, J. C. M.; FERREIRA, E. V. O.; GUEDES, M. N. S.; RAMOS, M. C. P.; CAMPOS, M. P. Nutrient absorption and accumulation in Paulista and Sabará jabuticaba cultivars. Revista Brasileira de Fruticultura, v. 40, n.5, 2018. http://dx.doi.org/10.1590/0100-29452018016

TAIZ, L.; ZEIGER, E. Fisiologia vegetal. Universitat Jaume I, 2006.

TÁVORA, F. J. A. F.; FERREIRA, R. G.; HERNANDEZ, F. F. F. Crescimento e relações hídricas em plantas de goiabeira submetidas a estresse salino com NaCl. Revista Brasileira de Fruticultura, v. 23, n.2, p. 441446, 2001. http://dx.doi.org/10.1590/S0100-29452001000200050

WAGNER JÚNIOR, A.; PALADINI, M.V.; DANNER, M.A.; MOURA, G.C.; GUOLLO, K.; NUNES, I.B. Aspects of the sensorial quality and nutraceuticals of Plinia cauliflora fruits. Acta Scientiarum. Agronomy, v. 39, n.4, p. 475-485, 2017. http://dx.doi.org/10.4025/actasciagron.v39i4.35420 